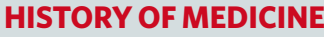 Ageing of plastic surgery
}

According to legend, the fourth-century twin martyrs Cosmas and Damian, patron saints of physicians, successfully transplanted a leg from a black donor to a white recipient - a surgical triumph depicted 11 centuries later in this German painting. The discarded white limb on the floor is among the least graphic casualties in A History of Plastic Surgery by Paolo SantoniRugiu and Philip Sykes (Springer, 2007).

The volume's 400 or so figures are testament to three millennia of piecing body parts together and reconstructing or correcting them for functional or cosmetic purposes. The authors have scrutinized rare ancient texts and drawings to gain insight into early medical practices, including the crucial adjuncts of anaesthesia, blood transfusion and treatment of infection, some of which survived for thousands of years. The Greeks, the Romans, the Arabs, the Renaissance, and battlefields galore, contributed to advances in plastic surgery.

The authors' final figure is intended to give the reader "something to smile about". It charts abdominoplasty techniques from 1948 - depicting darkly comical stout stomachs and pendulous abdomens.

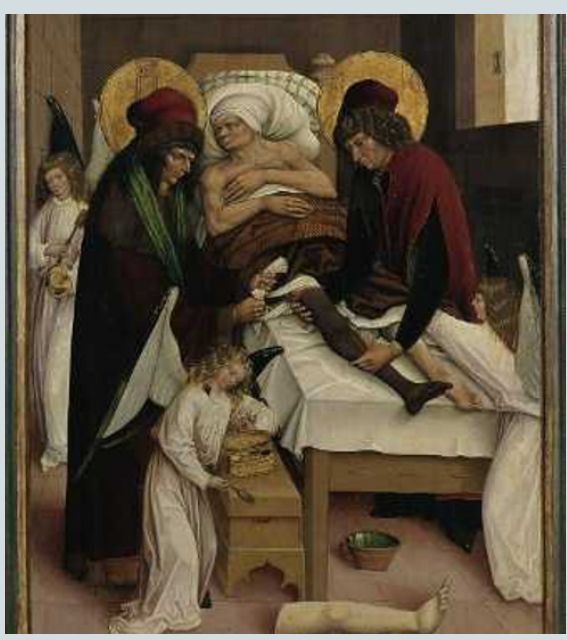

\section{The politics of mapping}

\author{
Cartography and power have long gone hand in hand, as this pilgrimage plan illustrates.
}

\section{Martin Kemp}

Maps exercise a fascination - it is reassuring and even commanding to be able to locate ourselves and others from a kind of God's-eye perspective. To misquote Descartes, "I am mapped, therefore I am."

Cartographers chart the familiar and accessible for various purposes, from travel to property rights. They give us a vivid concept of far-off lands to which we shall never journey. Armies have used maps to prosecute wars, and worshippers follow them on pilgrimages, actual or imagined.

The Bible has many geographical passages, and nothing for certain can be learned about the text unless we first study them. The whole course of scripture is governed by regions, cities, deserts, mountains and seas.

\section{A Christian with a grasp of biblical} geography can be a surrogate eye witness to the momentous events central to his religion. At least, this is what Roger Bacon claimed in his Opus Majus of 1267, in a section dedicated to 'Mathematics in the service of theology'.

"If the reader understands the geographical operation of the four elements, hot and cold, dry and damp, and the effects of the mixtures of these four ... he will be able to grasp and delight in the pure and literal sense of the Scriptures, and be able to advance with pride and confidence to their spiritual meaning," he writes.

The earliest illustrated travel book was devoted to the Holy Land. In 1486, Bernard von Breydenbach, a canon at Mainz Cathedral in Germany, published an account of his pilgrimage in his Pereginatio in Terram
Sanctum. He took with him the Dutch artist, Erhard Reuwich, who produced a great fold-out panorama centred grandly on the Dome of the Rock (Solomon's temple). von Breydenbach and Reuwick were more concerned with pictorial depiction and symbolic emphasis, however, than with precisely measured mapping.

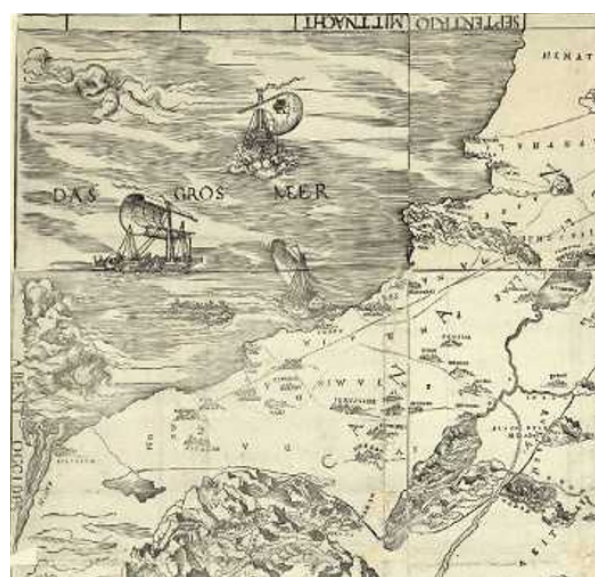

The most notable of the early maps of the Holy Land based on systematic measurement resulted from the 1493 pilgrimage by Elector Friedrich III of Saxony. The six-sheet woodcut (pictured) was almost certainly produced by Lucas Cranach the Elder, who became Friedrich's 'ducal painter' in 1505. It is discussed in the third magisterial volume of The History of Cartography, Cartography in the European Renaissance (University of Chicago Press, 2007), edited by David Woodward. The Elector secured Cranach's income by granting him a monopoly of the sale of medicines in Wittenberg and copyright in Bibles. Famed not least for his painted portrait of friend Martin Luther, Cranach was also a master print-maker. It is not known who provided the cartographic information.

Places with such resonant names as Galilee, Jerusalem, Bethlehem, Jericho and the River Jordan are duly assigned their places, and denoted by the little pictograms characteristic of Renaissance maps. The epic and perilous nature of Friedrich's pilgrimage is evoked by the galleons with billowing sails, the raging seas in the upper and middle left (the latter concealing a monstrous fish), and the excited landing party in their barge.

Here, as so often, religious devotion and territorial conflict are close companions. The Holy Land was the target of the crusading ambitions of popes and princes throughout the Middle Ages and the Renaissance. If we look at the ships crossing the sea, one is cresting proudly through the waves, bearing the Elector's shield on its sail. The lower one is a strange craft being blown forcefully in a contrary direction, and perhaps even travelling backwards. This seems to be Cranach's fanciful version of a hostile but thwarted Turkish man-at-war.

This piece of wishful thinking reminds us that cartography regularly served political ends. Cranach's map bears a militantly Christian message that contemporary viewers would not have missed. Looking at the map now, we realize that essentially the same contested interests of competing religions rule the unhappy history of the major sites today. 